\title{
NIT1 wt Allele
}

National Cancer Institute

\section{Source}

National Cancer Institute. NIT1 wt Allele. NCI Thesaurus. Code C126584.

Human NIT 1 wild-type allele is located within 1q21-q22 and is approximately $7 \mathrm{~kb}$ in length. This allele, which encodes nitrilase homolog 1 protein, is involved in both the catabolism of nitrogen compounds and the regulation of apoptosis. 